\title{
DIE REGSPOSISIE VAN DIE GEMOLESTEERDE KIND 1
}

\author{
Regter P.J. Schabort
}

\section{INLEIDING}

Hoe reik die reg uit na die seksueel gemolesteerde kind? As na die reg in wye verband gekyk word, sou dit alle wetgewing en alle gemeneregsbeginsels en alle regsprosedures insluit waardeur die Staat poog om molestering te voorkom en die gemolesteerde kind in beskerming te neem. Dit lê baie wyd en sou byvoorbeeld die maatreëls insluit van die Kinderwet 33 van 1960; die Wet op Egskeiding 70 van 1979; die Wet op Kindersong 74 van 1983; die Wet op die Status van Kinders 82 van 1987 en die Wet op Bemiddeling in Sekere Egskeidingsaangeleenthede 24 van 1987. Eersdaags sal dit moontlik ook'n Manifes vir die Regte van Kinders insluit wat vermoedelik geskoei sal wees op die VVO se Konvensie vir die Regte van die Kind (1989) waarvan die RSA tans nog nie 'n ondertekenaar is nie.

'n Bepaalde faset van die Staat se poging word aan sy strafregstelsel toevertrou. Dit is die funksie van die strafhof om deur bestraffing van'n molesteerder die onreg wat die kind en die samelewing aangedoen is, uit te wis. Hiervoor word sekere handelinge as misdrywe aangemerk en is 'n wet soos die Wet op Seksuele Misdrywe 23 van 1957 daargestel. 'n Belangrike vraag sou kon wees tot hoe 'n mate die Staat se strafregstelsel sy doel dien en waar daaraan verbeter kan word. Hier sou veral die Strafproseswet 51 van 1977 op die keper beskou moes word.

Dit is nie my bedoeling om 'n rede oor hierdie breë bestek van die gemolesteerde kind se regsposisie te lewer nie. Vergun my net enkele kantaantekeninge langs die onderwerp vanuit die gesigspunt van iemand wat ampshalwe hoofsaaklik by die strafregtelike proses betrokke is.

\footnotetext{
${ }^{1}$ Openingsrede gelewer op 15 Maart 1990 te Potchefstroom tydens 'n konferensic oor kindermishandeling - aangebied deur die Departement Privaatreg, PU vir CHO.
} 


\section{DIE REGSBELANGE VAN DIE KIND}

Ten aanvang, waaruit ontstaan die diepgrondige gebelgdheid van die samelewing oor die seksuele molestering van kinders? Anders gestel, welke belang van kinders wil die regstelsel as vertolker van die openbare regsbewussyn in hierdie verband beskerm? Samevattend sou ek sê dat dit die algemeen menslike reg op die respektering van die liggaamlike en geestelike integriteit is, iets wat in die geval van ' $n$ kind sy besonderse inhoud vind in sekere wesenseienskappe van 'n kind waarvan ek enkeles aanstip:

- die geslagsonrypheid van 'n kind binne die dampkring van volwasse seksualiteit;

- die sedelike onskuld van 'n kind te midde van sedelike verdorwenheid in die geledere van volwassenes;

- die onkundigheid en onbedrewenheid van 'n kind in die wêreld van volwasse kennis en ervaring;

- die afhanklikheid en weerloosheid van 'n kind teenoor sy psigiese en fisiese meerderes;

- die potensiaal van die volwassene in die kind;

en

- les bes, die aanspraak van 'n kind om een maal in sy volheid kind te kan wees, met onder meer die geleentheid om die weg van seksualiteit te vind en geleidelik daarop voort te beweeg sonder om in die strikke van 'n seksuele struikrower verstrengel te raak.

Is hierdie moontlik 'n oordrewe sentimentele siening van kindwees? Berus dit op 'n oordrewe idealistiese beskouing van die werklikheid? In menige gevalle, bes moontlik, ja. Per slot van rekening lê hierdie terrein op die grondvlak van die menslike natuur en raak dit plek-plek aan die kraakplek in ons aardse fondasie. Hieraan moet toegevoeg word dat seksuele molestering, soos verskeie ander kwellings, bedreiginge en tragedies wat die kinderlewe kan aanveg, in alle tye voorgekom het en dat die menslike vermoë steeds verstommend was om terugslae te oorkom, dit te verwerk en te oorleef.

Miskien moet hierdie perspektief net behou word by besinning oor die vraagstuk van 
kindermolestering te midde van die ernstige strewe na beswering van die verskynsel. Te dikwels word in uitlatings en in hofuitsprake die veronderstelling aangetref, ongevestig in wetenskaplike bewyse, dat 'n bepaalde seksueel gemolesteerde kind sekere nadelige gevolge van sy of haar ervaring sal oorhou. Natuurlik is daar graadverskille van molestering en uiteenlopende omstandighede in sake en die intrede van nadeel kan soms wel tasbaar en ooglopend blyk. Die versigtige en ervare beoordelaar van feite sal in hierdie opsig egter op die hoede bly. Met verwysing na verskeie gesaghebbende werke, verklaar prof. J.M.T. Labuschagne in 'n artikel onder die opskrif "Ouderdomsgrense en die bestraffing van pedofilie" (1990) 1 SAS 13 dat dit die opvatting onder wetenskaplikes is dat emosionele nadeel, op die kort- of die langtermyn, moontlik is maar nie noodwendig op pedofiliese handelinge volg nie.

\section{DIE ROL VAN DIE HOOGGEREGSHOF}

Ter wille van die oningewydes wat die howe-opset betref, word vervolgens een en ander gesê oor die plek van die hooggeregshof in die verband van kindermolesteringsake.

Die geregshof waarin kindermolestering primêr ter sprake is, is die landdroshof en veral die streekhof weens sy hoë strafbevoegdheid. 'n Streekhof kan tot 10 jaar gevangenisstraf oplê en tot R20000 beboet.

In gevalle waar daar van kindermolestering binne die verband van menseroof, kinderdiefstal of verkragting sprake is; dit wil sê misdade waarvoor die doodstraf opgelê kan word, of in ander uitsonderlike gevalle, sou die prokureur-generaal wel in die hooggeregshof kon vervolg. Dit word egter net in erge gevalle gedoen.

In alledaagse gevalle van kindermolestering is die hooggeregshof dus net betrokke by wyse van hersieningsake en in appelle.

Wat hersienings betref, bestaan daar eerstens die instelling van outomatiese hersiening. Dit geld waar 'n persoon by sy verhoor nie oor 'n regsverteenwoordiger beskik het nie en het betrekking op vonnisse van 'n sekere aard en omvang en met inagneming van landdroste se senioriteit. Daar is geen outomatiese hersiening vanaf die streekhof nie.

Weens die strawwe wat normaalweg vir kindermolestering opgelê word, gebeur dit baie dikwels dat veroordelings weens kindermolestering by wyse van outomatiese 
hersiening voor die hooggeregshof beland. As voorbeeld sou na die onlangs gerapporteerde saak van $S$ v D 19894 SA 709 (T) verwys kan word. Daarin het die landdros'n vader wat sy agt- en tienjarige stiefdogters onsedelik aangerand het vir twaalf maande tronk toe gestuur. Wat op hersiening gebeur het, meld ek later.

In hierdie verband kan daarop gewys word dat die sinvolheid van die instelling van outomatiese hersiening oor die algemeen genoegsaam bewys is as 'n hulpmiddel om die standaard van regspraak in die landdroshof te bevorder en, in gepaste gevalle, as maatreël om te verseker dat reg geskied.

'n Ander verskyningsvorm van hersiening staan as spesiale hersiening bekend. Spesiale hersiening geskied ingevolge artikel 304(4) van die Strafproseswet 1977. Spesiale hersiening vind plaas waar 'n landdroshof 'n vonnis opgelê het wat nie aan outomatiese hersiening onderworpe is nie of waar die streekhof 'n vonnis opgele het en dit dan onder die aandag van die hooggeregshof gebring word of dit onder die aandag van die hooggeregshof kom dat "die verrigtinge waarin die vonnis opgelê is, nie ooreenkomstig die reg was nie". So sou 'n regter wat 'n koerantberig lees en die indruk kry dat 'n skuldigbevinding of vonnis nie ooreenkomstig die reg was nie, die landdroshofoorkonde kon aanvra en die saak in hersiening neem.

Hierdie bevoegdheid van die hooggeregshof in die hiërargie van ons strafhofstelsel is van die hoogste waarde by die nastrewing van die ideaal dat reg oral en onder alle omstandighede geskied. Landdroste, insluitende streeklanddroste, maak dikwels van hierdie maatreël gebruik om gevalle aan die hooggeregshof voor te lê waar byvoorbeeld weens 'n oorsig tot die besef geraak word dat 'n regtens ongeoorloofde vonnis opgelê is. Self sou die laerhof die saak nie kon regstel nie omdat dit functus officio is.

Dic voorafgaande was dan bedoel om aan te toon hoe die hooggeregshof gewoonweg hy sake van kindermolestering betrokke raak. Dit kom daarop neer dat die saak reeds bereg is in die laerhof en dat die hooggeregshof se bemoeiing beperk is tot oorweging van die vraag of alles daar volgens die eise van die reg verloop het.

\section{DIE HOOGGEREGSHOF AS OPPERVOOG}

Vervolgens word die lig gewerp op 'n besondere hoedanigheid van die hooggeregshof waarop die publiek dikwels nie genoegsaam bedag is nie. Die hooggeregshof is die oppervoog van alle minderjarige kinders. Dit is 'n regsbevoegdheid wat uit die gemene 
reg voortvloei en regters met 'n besondere gesag en ingesteldheid beklee - iets wat diep gekoester word en regtens noop om oral en in alle omstandighede 'n wakende oog te hou oor die lotgevalle en belange van minderjariges. Hierdie regsbevoegdheid kan sy toepassing vind by ingrepe ingevolge die spesiale hersieningsbevoegdheid waarna ek verwys het, by inmenging met onredelike ouerlike of voogdelike optrede, by egskeidingsgedinge waar minderjariges betrokke is en oral waar dit 'n regter opval dat 'n minderjarige die hulp en beskerming van 'n oppervoog benodig.

So word regters en is ek ook onlangs deur 'n lid van die publiek genader in verband met 'n geval van beweerde kindermolestering en kon ek die aangeleentheid vir dringende opvolging deur die betrokke owerheidsinstansie verwys.

Hoe ingrypend hierdie bevoegdheid in die raamwerk van ons adversariese regsisteem is, blyk daaruit dat ' $n$ regter as oppervoog uit eie beweging, desnoods, 'n curator ad litem kan aanstel om namens 'n minderjarige in hofverrigtinge op te tree waar laasgenoemde se belange met dié van sy ouer of voog bots of moontlik kan bots. Die hof sou ook in sekere omstandighede die bevoegdheid van enige buitestaander erken om regstappe te neem ten einde 'n minderjarige se belange in beskerming te neem. In gepaste omstandighede sou 'n regter in sekere siviele hofverrigtinge ook uit eie beweging en ongeag die houding van die partye daaromtrent, 'n persoon voor die hof kon daag as getuie. Dít is 'n belangrike uitsondering op die reël wat in siviele sake geld. In strafsake is die posisie anders. Daar sou die hof wanneer dit ook al in belang van geregtigheid nodig geag word, persone uit eie beweging as getuies kon oproep.

Teen die agtergrond van wat ek tot dusver gesê het wil ek by hierdie geleentheid graag onderstreep dat een en almal met sekerheid moet weet dat die hooggeregshof enersyds as oppervoog van alle minderjariges en andersins, en dat al die ander howe van ons land insgelyks, die belange van minderjariges en in besonder ook dié van kinders ten seerste op die hart dra en voortdurend daarna streef om dit optimaal te beskerm. Hiertoe is die howe regtens geroepe en daarop is hulle intens ingestel.

Tot welke mate daarin geslaag word om aan hierdie ideaal rondom die problematiek van die gemolesteerde kind te voldoen, is natuurlik'n ander vraag. My eie indruk en ervaring is dat die worsteling om metodes en oplossings te vind vir die byna verbysterende reeks netelighede rondom die hofproses, bewyslewering en straftoemeting, nog lank nie verby is nie.

Dekriminalisering van kindermolestering en kindermishandeling sal, soos dit vir my lyk, in ons tyd met stelligheid uitbly. Klaarblyklik is nog geen doeltreffende en 
regverdige stelsel beskikbaar of in sig vir die uitwissing of bedwinging van hierdie verskynsel buite om die geregtelike proses met sy bestraffende, afskrikkende, dwingende en hopelik opheffende gesag nie. Tewens, namate gedraginge van hierdie aard meer en meer in ons samelewing voorkom en /of weens toenemende maatskaplike bedagtheid meer dikwels aan die kaak gestel word, sal die howe ter behoorlike volvoering van hulle taak maar net na verdieping van insig, kundigheid en oordeel daaromtrent kan streef. 'n Byeenkoms van die huidige aard kan gevolglik net as tydig en gewens bestempel word en is ek seker dat kollegas my die voorreg om hierin te kan deel, beny. Vir ons doen sulke geleenthede hul maar selde voor.

\section{ONTWIKKELINGSPEIL VAN 'N KLAER/KLAAGSTER}

'n Aspek van die problematiek van kindermolestering en die beoordeling daarvan in 'n geregshof het betrekking op die bepaalde klaagster of klaer se ontwikkelingspeil op die leer van volwasse seksualiteit. Dit is van belang by die beoordeling van die klaagster of klaer se getuienis en by gepaste strafoplegging van 'n veroordeelde molesteerder. Waar kindwees eindig en volwassenheid begin, bestaan natuurlik geen raakvlak nie. Iewers tussenin lê die newelagtige en rekbare landskap van die jeugdelike oorgangsjare, 'n fase waarop nòg die kind nòg die volwassene aanspraak kan maak. Hier bied chronologiese perke soos in verskeie wette aan te tref is, maar 'n growwe maatstaf. In artikel 14 van die Wet op Seksuele Misdrywe 23 van 1957 word byvoorbeeld ouderdomsgrense van 16 jaar en 19 jaar gestel vir sekere oortredings en in die Wysingswet op Huwelike 51 van 1970 word die hubaarheidsouderdom vir meisies op vyftien jaar gestel en dié vir seuns op agtien jaar, dit wil sê dan het hulle nie meer ministeriële toestemming nodig om te kan trou nie. Daarmé sou 'n dogter reeds op twaalf- en 'n seun op veertienjarige leeftyd kon trou, mits hulle ouers of voogde natuurlik toestemming gee. Hierdie punt kan met 'n voorbeeld toegelig word. Gedurende April 1990 was 'n 49-jarige stiefoupa se skuldigbevinding aan die pleging van 'n onbehoorlike daad met sy elfjarige standerd 3-stiefdogter ter sprake. In 'n uitspraak op appel voor die hooggeregshof in Pretoria verklaar die geleerde Regter onder meer die volgende:

Daar is geen twyfel op die getuicnis dat dic klaagster die verleidster was en dat die appellant 'n volle geleentheid sou gehad het om gemeenskap met haar te hou, indien hy wou (nic). 
Elders in die uitspraak word gesê:

Die klaagster is bewys as promisku en korrup. Sy het die appellant op haar eie getuienis verlei. Sy is geslagtelik ryp, ver bokant haar ouderdom. Die moontlikheid bestaan op dic getuienis dat sy mot' $n$ ander man alreeds gemeenskap gehad het. Sy het erken dat sy die episodes geniet het. Selfs nadat sy met dic ortopedagoog daaroor gepraat het, het sy weer die appellant verlei.

Verder aan:

Daar is geen bewys dat (die appellant) enige fisiese of psigiese skade veroorsaak het nie en hy is verlei deur 'n spreckwoordelike lolita van tien na elf jaar oud. Dit bly maar 'n ernstige misdaad en ck gaan 'n lang periode gevangenisstraf oplê. Dit moet gedoen word in die lig van die feit dat daar vier aparte dade was en dat hierdie dade oor ten minste 'n periode van twee jaar gestrek het.

Die appellant is gevonnis tot twee jaar gevangenisstraf wat vir vyf jaar opgeskort is op voorwaarde dat hy nie skuldig bevind word aan onsedelike aanranding of ' $n$ oortreding van artikel 14(1)(a), (b) of (c) van Wet 23 van 1957, gepleeg gedurende die opskortingstermyn nie. (A 1466/89)

Op 16 Mei 1990 verskyn 'n berig in Beeld van 'n swanger negejarige meisie in Malawi wat bevrug is deur 'n sestienjarige seun; op dieselfde datum word op 'n TV 1-program gestel dat oor die algemeen, swart skoliere seksueel aktief is; in Time Magazine van 14 Mei 1990 lees ek dat

... youngsters in China are maturing a year earlicr than their grandparents did a half-century

ago, thanks in part to improved nutrition, with $91,5 \%$ of girls menstruating before the age of 14 .

Hier moet natuurlik onthou word dat ongeveer een uit elke vyf mense op aarde 'n Chinees is. Wat die posisie in hierdie opsig in die Nywerheidslande is waar nog beter geëet word as onder die Chinese massas, is 'n oop vraag, maar die neiging is stellig nie anders nie. In sy gernelde artikel toon prof. Labuschagne inderdaad aan dat volgens sekere studies kinders vandag al hoe jonger en al hoe meer seksueel aktief is. So noem hy dat volgens nasionale opnames in die VSA die gemiddelde ouderdom waarop meisies daar vir die eerste keer geslagsomgang het, ongeveer dertien jaar is. Hy meld voorts dat uit navorsing wat in Switserland onderneem is ten aansien van pedofiliese dade wat met meisies tussen twaalf en sestien jaar gepleeg is, in $70 \%$ van die gevalle die meisies die man geprovokeer het en dat $54 \%$ van hierdie meisies reeds vroeër seksuelc ondervinding gehad het.

Nader tuis en gelukkig in wettig verband: Paul Kruger was sewentien jaar oud toe hy getroud is. Louis Trichardt se vrou, Martha Bouwer, was vyftien jaar oud en Susanna Smit, die vrou van eerwaarde Erasmus Smit, was skaars veertien toe hulle getroud is. 
My een ouma was, soos dit genoem is, in haar sewentiende jaar, dit wil sê sestien jaar oud toe sy getroud is. 'n Gelukkige huwelikslewe van nege-en-sestig jaar het daarop gevolg.

Wat ek met die voorafgaande te kenne wil gee is net dat juridiese oordeel rondom misdaad en straf soms op bra onhandelbare gegewens uitgeoefen moet word. Die begrip kind op die vlak van die seksuele bestaan bly egter 'n netelige kwessie.

\section{BESKERMING VAN DIE ONGEBORENES}

Alhoewel dit met "molestering" soos dit by hierdie geleentheid ter sprake is, niks te make het nie, wil ek graag 'n aangeleentheid opper in die wete dat u hier is weens'n besondere belangstelling in of geroepenheid betreffende die belange van kinders.

Ek het gesê dat dit hoogs relevant, maar moeilik is om te bepaal wanneer iemand werklik ophou om "kind" te wees. 'n Aantal jare gelede het ek voor die raaisel te staan gekom van wanneer iemand in 'n sin begin om "kind" te wees. Dít was toe ek as advokaat geraadpleeg is deur ' $n$ interkerklike instansie met die benaming Christian League of Southern Africa. Ek is meegedeel dat 'n ongebore kind in Bloemfontein tot die dood toe in 'n stryd gewikkel was teen sy eie ma ('n ongetroude meisie), haar pa en 'n sekere psigiater wat alles in hulle vermoë probeer doen het om 'n aborsie kragtens die Wet op Vrugafdrywing en Sterilisasie 2 van 1975 te probeer verkry. Die bevordering van die Christelike etiek hier te lande was 'n doelstelling van my kliënt en dit is as 'n taak gesien om in hierdie stryd toe te tree as 'n beskermer van die ongeborene se regte. In die proses is ook gepoog om die maatskappy bedag te maak op die bedreiging vir die Christelike lewensbeskouing - 'n bedreiging op grond van die sogenaamde liberalisering van aborsie, of soos ons dit in sekere lande ken, as aborsie op aanvraag.

Die moeder het aanvanklik as 'n grond vir wettige aborsie aangevoer dat sy rottegif gedrink het en dat dit die fetus kon beskadig het. Toe die geneeshere geweier het om hierdie deursigtige storie te aanvaar, het sy gedreig om selfmoord te pleeg weens haar swangerskap. So, is gedink, kon 'n grond geskep word vir wettige aborsie op die basis dat die swangerskap 'n bedreiging was vir haar lewe. Die geneeshere het hulle egter nie laat afpers op hierdie wyse nie. Uiteindelik is beweer dat sy verkrag was. Dít sou ook 'n wettige aborsie kon verseker mits 'n landdros sou bevind dat sy wel verkrag is. Teen die moontlikheid dat 'n landdros so 'n bevinding foutiewelik kon maak, wou die Christian League waak.

Daar moes naarstiglik gedink word aan 'n gepaste remedie. Feitlik oornag moes hofstukke voorberei word. Die saak was res nova; nuwe reg moes geskep word. Die Vry- 
staatse Hooggeregshof is gevra om 'n curator ad litem aan te stel om die ongeborene, alleen en onbeholpe soos hy was, te verteenwoordig in die regsproses voor die landdros.

Vandag is hierdie hofsaak geskiedenis en elke student van ons personereg word iets daarvan vertel. Die geval het 'n gelukkige uiteinde gehad. Iewers in die Vrystaat draf 'n seuntjie waarskynlik nou uit vir sy skool se onder 11-rugbyspannetjie. Die regsbeginsel dat 'n ongeborene in dergelike omstandighede op 'n curator ad litem geregtig is, het egter skipbreuk gely. Hieromtrent het verskeie skrywers sedertdien deurtastend kommentaar gelewer in artikels in regstydskrifte.

Gedagtig aan die individuele menslike wesenheid van 'n ongeborene in die lig van die mediese kennis van vandag en die Christelike etiek betreffende ongeborenes, en gedagtig aan die onvermoë van ongeborenes om hulself teen bedreiging te beskerm en aan die voorkoms van aborsie in ons land, betaam dit tydig en ontydig waar oor die welsyn van kinders besin word, om die ongeborenes in ons midde en hulle regsposisie nie te vergeet nie.

In die jongste artikel oor hierdie saak in 1990 TSAR 4459 sluit prof. Lourens du Plessis, tans van die Universiteit van Stellenbosch, af met die volgende voorstel: I suggest that the Act [dit is die Wet op Vrugafdrywing en Sterilisasie 2 van 1975] be amended so
as to provide for judicial proceedings in each instance where an abortion on onc of the grounds
provided for in the Act is sought. The person secking the abortion should then be required to
bring an application to either a court of law or a specialist tribunal ... Provision should be made
for the appointment of a curator ad litem as a matter of course. The curator must represent the
unborn child in the said proceedings, which should be adversary in nature leaving the curator
with the right to cross-examine witnesses. This is the least the law can do to recognize the
personality of the unborn in the process of making a decision which goes to the root of its
continued existence.

A truc liberalization of abortion legislation will be directed at the increased protection of the foctus's basic right to live - not at its increased subversion.

Volgens gegewens tot my beskikking het 927 wit moeders in 1989 aborsies ingevolge die bepalings van die genoemde Wet ondergaan. In 'n rede voor die Mediese Vereniging in Johannesburg het 'n senior ginekoloog onlangs onder meer die volgende verklaar:

Some pcople will object to the word "kill" when speaking of abortion. But one cannot abort an unborn child without killing it. The fact is that the child is alive before the procedure and is dead when it is over. The mortality of this "treatment" is always $100 \%$. Sometimes the killing can be quite gruesome. The agony and excruciating torture of a sixteen weeks highly developed unborn human being when being dismembered, disemboweled and crushed, or when saline or prostaglandin is injected into the amniotic sac has yet to be determined by medical science. 
Volgens The Sunday Star van 30 Oktober 1988 was daar volgens die Abortion Reform Action Group na skatting 300000 onwettige aborsies in Suid-Afrika in 1987, afgesien van diegene wat oorsee sogenaamde wettige aborsies ondergaan het. (1989 Businesman's Law 158)

\section{PROBLEMATIEK VAN STRAFTOEMETING}

Nou, na hierdie afdwaling, keer ek terug na 'n laaste kantaantekening rakende die regspc.sisie van die gemolesteerde kind: die kwessie van straftoemeting.

Dit is nie net die gevonnisde wat 'n belang het by sy straf nie. Soos voorheen aangedui, behoort die straf die skaal van geregtigheid tussen klaer en gestrafde in ewewig te herstel en moet dit plaasvind op die draaispil van die openbare belang. Die openbare belang verg onder meer dat ' $n$ vonnis behoorlike afskrikwaarde moet hê maar ook gerig moet wees op behoorlike hervorming van die oortreder.

Dit is doenlik om dadelik te blaai na die uitspraak waarna vroeër verwys is: $S \vee D$. Hierdie was 'n geval van molestering in gesinsverband en was deurspek van kommentaar oor die "heel besondere vorm van sosiaal afwykende gedrag" waaroor dit in sulke sake gaan, "enersyds vanweë die proteaanse verskyningsvorms, aanleidende psigoseksuele, maatskaplike en gesinsoorsake" daarvan "asook van die voorkoming van herhaling daarvan en die herstel van die gevolge daarvan". Voorts word gemeld dat "(s)eksuele peutering met kinders binne gesinsverband ... meermale 'n manifestasie van gesinspatologie" is, iets wat vereis dat die pleger se handelinge, blaamwaardigheid en geregtelike lot bepaal moet word deur 'n ondersoek, nie alleen van die beskuldigde nie, maar ook van die gesin.

Die landdros het by vonnisoplegging nie beskik oor 'n tersaaklike welsynsverslag of ander vakkundige getuienis betreffende die oortreder of sy gesin, die samestelling daarvan, die interaksie daarbinne of toekomsvooruitsigte daarvan nie.

In hierdie omstandighede het die hof die vonnis tersyde gestel en die saak na die landdros terugverwys vir die verkryging van deskundige getuienis deur 'n maatskaplike werker en sodanige ander deskundige as wat of die landdros of die maatskaplike werker goed sou ag aangaande die beskuldigde, die klaagster en hul gesin. Wat die verdere geskiedenis van hierdie geval voor die landdros was, is aan my onbekend. Dit mag wees, soos die betrokke regter ook in vooruitsig gestel het, dat die landdros na alles weer dieselfde vonnis kon opgelê het. Hy stel dit so: 
Dit mag na behoorlike ondersoek blyk dat die landdros gelyk had toe hy besluit het dat regstreckse gevangenisstraf aangewese is. Maar dan sal dit 'n prinsipieel suiwere vonnisbepaling wees. Dit mag egter ook - en meer waarskynlik - blyk dat een of ander vorm van verpligte behandeling (van dic beskuldigde en van die gesin) onder die sanksie van 'n geheel opgeskorte vonnis van gevangenisstraf verkieslik is. In die verband het ek in gedagte die soort bevel wat in $S v S 19773$ SA 830 (A) en in $S v B 19803$ SA 846 (A) deur Rumpff HR geformuleer is. Bestudering van beide uitsprake, veral om te let op die wyse waarmee daar met geslagsafwykendes gehandel is, sal die landdros en enige deskundige(s) wat geraadpleeg word tot voordeel strek. Eersgenoem de was 'n geval waar ' $n$ onderwyser oor 'n langdurige tydperk drie jong dogtertjies in sy klas seksucel gemolesteer het. Laasgenoemde beskuldigde was 'n volhardende ontbloter. In sy geval sê die geleerde Hoofregter, op 851C-D: "Appellant is betreklik jonk cn dit is van belang vir die behoud van sy familic, sy vrou en sy klein kinders, maar ook spesiaal in die belang van die samelewing, dat 'n ernstigc poging aangewend word om hierdie man te genees."

Dit mag wel blyk kommentaar te wees wat op die huidige geval van toepassing is.

Hierdie uitspraak, waarmee die Regter-president saamgestem het, is 'n rigtinggewende gewysde wat dergelike gevalle betref en laerhowe sal in die toekoms daarop let. Miskien sê dit niks nuuts wanneer die wenslikheid daarin aangedui word om deskundiges vir die doeleindes van vonnistoemeting by die regsproses te betrek nie. Dit beklemtoon hierdie aspek egter opnuut en in onomwonde taal.

\section{DESKUNDIGE HULPDIENSTE IN DIE GEVANGENIS}

Rondom straftoemeting word die klem laastens op 'n aspek laat val wat enkele maande gelede in ' $n$ ander appèlsaak in Pretoria ter sprake was.

'n Dertigjarige man het by 'n gesin in die Vaaldriehoek loseer. Hy het 'n buitekamer met ' $n$ veertienjarige seun gedeel en het die seun met geskenke vertroetel en bevriend en oor die loop van ' $n$ aantal maande drie keer tot sodomie verlei. Die landdros het die beskuldigde drie jaar gevangenisstraf opgelê. Geen deskundige getuienis is voor vonnisoplegging deur die Staat, die hof of die beskuldigde aangebied nie.

Op appèl is aangevoer dat die landdros in laasgenoemde opsig gefouteer het en dat die geleentheid aan die beskuldigde gebied moes word om sielkundige getuienis voor te lê nadat die saak na die landdros terugverwys is vir daardie doel. Voorts is aangevoer dat die vonnis skokkend hoog was en dat die hof daarmee moes inmeng.

Hierdie helc betoog is verwerp omdat die beskuldigde wat vorige veroordelings weens diefstal en die bestuur van 'n motorvoertuig onder die invloed van drank gehad het en gevolglik geen onervarene in die hofopset was nie, by sy verhoor nie gevra het dat vakkundige getuienis aangebied word nie. Ook het hy nie uit eie beweging sielkundige hulp gesoek na sy episode met die seun nie en het hy ook geen getuienis voor die hof van appèl probeer plaas om aan te toon dat daar 'n vooruitsig op sodanige getuienis 
was wat hom sou begunstig nie. Die appèl is gevolglik van die hand gewys. Die hof het egter aanbeveel dat die appellant in die gevangenis sielkundig geëvalueer word met die oog op gepaste sielkundige en ander behandeling tydens sy verblyf in die gevangenis. 'n Kompliserende faktor in hierdie saak was, terloops, die feit dat die appellant 'n Vigsdraer was. Die landdros het egter aanvaar dat hy nie daarvan bewus was toe die misdrywe gepleeg is nie.

Hoewel daar dus van hierdie saak korte mette gemaak is op appèl, het die behoefte aan geskikte en genoegsame deskundige hulpdienste in die gevangenis duidelik na vore getree. Hierdie hulpdienste kon aangewend gewees het vir die behoorlike rehabilitasie van die betrokkene betreffende sy oënskynlike pedofilie en perversiteit. Gebeur dit nie, sou die moontlike gevolge van sy toekomstige seksuele vergrype skrikwekkend kon wees.

Omdat hierdie 'n geval was waar die oortreder kwalik uit die gevangenis gehou kon word, het die soeklig in hierdie saak skerp op die beskikbaarheid van die genoemde deskundige bystandsdienste in die gevangenis geval. Dit is hier waar daar moontlik 'n kommerwekkende situasie bestaan. Ek knoop dit aan die volgende:

In die pasverskene Jaanerslag vir 1989 van die S.A. Gevangenisdiens, word die volgende onder die opskrif "Sielkundige Dienste (Personeel)" vermeld:

Vergeleke met dic vorige verslagjaar het die diensstaat posisie in die verslagtydperk heelwat verswak. Een sielkundige het in die verslagtydperk diens aanvaar en drie het bedank.

Op 30 Junie 1989 was daar altesaam 36 poste in die Onderafdeling Sielkundige Dicnstc, waarvan 28 gevul is. Ondanks verskeic advertensies in die media kon hicrdie vakatures tot aan die einde van die verslagjaar nog nie gevul word nie.

Hierdie gegewens moet in ag geneem word teen die agtergrond van die feit dat daar volgens hierdie verslag op 30 Junie 198971053 prisoniers van alle rasse wat tot twee jaar en langer gevangenisstraf gevonnis is, in ons tronke was. Hierteenoor, 28 gevulde poste vir sielkundige dienste! 'n Klaarblyklik onbegonne taak.

In $S \vee D 19894$ SA 225 ('n geval van 'n pedofiel, die direkteur van 'n kinderdramagroep) het die Kaapse Hooggeregshof op appel bevind dat ten spyte van 'n kolonel van die gevangenisdiens se getuienis tot die teendeel, daar by die Pollsmoor Gevangenis nie bevredigende sielkundige hulp vir die veroordeelde was nie. Die hof het gevolglik ingegryp wat die straf betref wat in die landdroshof opgelè is en 'n vonnis opgelê wat onder meer behels het dat die veroordeelde na verstryking van 'n termyn gevangenisstraf hom onderwerp aan sielkundige behandeling by die Valkenburg-Hospitaal. 
In $S v$ Reay 19871 SA 873 was die geval ter sprake van 'n dwelmverslaafde jongman wat by apteke ingebreek het om dwelms en geld vir dwelms te bekom. Hy is deur die streekhof gevangenisstraf opgelè. Dit het geblyk dat hy nie 'n werklike kriminele tipe was nie maar 'n verslaafde. Op die tydstip dat die saak voor die Appèlafdeling van die Hooggeregshof gedien het, was die betrokkene reeds twee jaar lank in die gevangenis, maar dit het geblyk dat hy nog steeds geen sielkundige behandeling ontvang het nie. Dít was die toedrag van sake, ten spyte daarvan dat die Regter-president van Transvaal toe die saak aanvanklik op appèl voor die Hooggeregshof in Pretoria gedien het, gevra het dat die betrokkene sielkundig geëvalueer word in die gevangenis. (Appèlsaak no. A $17 / 1985$ T.)

Ek sluit af met sekere opmerkings van die Adjunk-regter-president van die Witwatersrandse Plaaslike Afdeling van die Hooggeregshof gedurende Februarie verlede jaar in ' $n$ appèlsaak betreffende ' $n$ veroordeelde pedofiel.

Judges and magistrates, generally, know that psychological treatment is provided for some prisoners who have committed crimes while suffering from psychological disorders, but that does not mean that a sentencing judicial officer can safely assume that the request or "order" that a prisoner is to undergo psychological evaluation will result in the administration of rehabilitative psychotherapy to a prisoner. Moreover, there lurks a distinct danger in a vaguc impression or an assumption that psychotherapy might be available to a prisoner. It could, I think, influence a judicial officer, who is not on his guard, in thinking that a "long term" sentence is a more suitable sentence to impose on an accused than one of less than two years imprisonment, since it results in beneficial psychological treatment being administered to the prisoner. ( $S \vee$ Weise A $385 / 89$ )

As daar 'n behoefte bestaan dat veroordeelde kindermolesteerders in sekere gevalle onopgeskorte gevangenisstraf opgelê moet word, en daar is sulke gevalle, sal die Staat moet verseker dat daar te alle tye afdoende deskundige hulpdienste in die gevangenis beskikbaar is om die benodigde rehabilitatiewe bystand te kan verleen. 
